\author{
REVIEW OF EUROPEAN AND COMPARATIVE LAW \\ VOLUME XLIII \\ YEAR 2020, ISSUE 4, pp. 139-162 \\ DOI: https://doi.org/10.31743/recl.9851
}

\title{
RUSSIANS ON THE POLISH LABOUR MARKET
}

\author{
Krystyna Gomótka*
}

\begin{abstract}
The article looks into the employment of Russian citizens in Poland in 2004-2018. It presents the legal basis for Russians' entering Poland and taking up work without having to seek a work permit, and specifies who must apply for such a permit. Russian citizens can obtain refugee status under the Geneva Convention, which grants them the right to move freely, choose their place of residence and undertake paid employment, while guaranteeing social security. On the basis of the Act on granting protection to aliens, citizens of the Russian Federation may obtain subsidiary protection if their return to their country of origin may expose them to a real risk of serious harm. A tolerated stay is granted to aliens where an alien might be expelled to a country in which their life, freedom and personal security would be jeopardised, where they could be subjected to torture, degrading treatment, humiliation, forced to work or deprived of the right to a fair trial. Training and employment can be undertaken in Poland under the bilateral agreements between Poland and Russia: the Treaty on friendly and good-neighbourly cooperation and the Cooperation Agreement in the fields of science, culture and education. In Poland, the entry and stay of foreign nationals is governed by the Act on aliens, their education by the Higher Education Act, whereas the employment of foreigners is regulated by the Act on employment promotion and labour market institutions.
\end{abstract}

* Prof. Dr. habil. Krystyna Gomółka, Professor, Faculty of Management and Economics, Gdańsk University of Technology; correspondence address: Traugutta 79, Gdańsk 80-233, Poland; e-mail: kgom@zie.pg.gda.pl; https://orcid.org/0000-0002-70460729. 
The empirical basis of the study was provided by the analysis of data from the Polish Ministry of Family, Labour and Social Policy and the Demographic Yearbook. Russians constitute the third largest group (after Ukrainians and Belarusians) of the post-Soviet States' citizens coming to Poland. The analysis conducted showed that employment in Poland was chiefly sought by the citizens of the Russian Federation who arrived in Poland for a limited period and for permanent residence. In 2004, the Russians represented $4.4 \%$ and in $2018-0,66 \%$ of all foreigners who received work permits in Poland. Before 2015 some Russian nationals took up work in Poland as the managers of their own companies. Since 2015, there has been an influx of workers from Russia in three occupational groups: IT specialists, skilled workers and workers in elementary occupations. Most of the Russians were employed in the wholesale and retail, information and communication, construction, transport and warehousing sectors, which were the same sectors where Polish entrepreneurs reported demand for Russian workers. The demand significantly exceeded the number of Russians employed.

Keywords: Russians, labour market, work permit, professions practised, national economy sectors

\section{RUSSIANS WORKERS ON THE POLISH LABOUR MARKET AS THE SUBJECT OF RESEARCH. LITERATURE}

This study focuses on the presence of Russians on the Polish labour market between 2004 and 2018. The employment of citizens of the Russian Federation in this market is an important subject of research for a number of reasons. Russian Federation citizens are among the three most numerous groups of foreigners arriving in Poland - after Ukrainians and Belarusians. Polish legislation offers many employment opportunities for foreigners legally residing in Poland regardless of the length of their stay, while precisely specifying who needs a work permit and who does not need to apply for it. This study is intended to show which groups of Russian citizens are most likely to take up work in Poland, and which ones are not interested in employment. It also aims to provide information on the number of Russians who receive work permits and what share of foreigners employed in the Polish labour market they represent. The data analysed is intended to provide information on the type of employment undertaken by Russians according to the Polish classification of business activities 
$(\text { PKD code })^{1}$ and selected occupational groups and professions. Analysis of the employment data should identify the national economy sectors in which Polish employers chose to hire Russian workers.

The employment of immigrants in Poland has been given much attention in literature. The largest number of analyses and studies are concerned with workers from Ukraine, who account for about $80 \%$ of all workers from the post-Soviet countries employed in Poland. The study by Brudnarska, Grothe and Lesińska shows the migration of Ukrainian citizens in the context of socio-economic development ${ }^{2}$. Binkowski defines the role of Ukrainians in the Polish labour market ${ }^{3}$, whereas Szpakowska, Buchwald and Romanowski demonstrate the attractiveness of the Polish labour market for Ukrainians ${ }^{4}$. The expectations and needs of Ukrainians in Poland are the focal point of the publication edited by Lubicz Miszewski ${ }^{5}$. Przemyślańska-Włosek presents the opinions of Ukrainians on working in Poland, based on survey results ${ }^{6}$.

There are fewer publications that analyse the employment of foreign nationals in Poland. Poland's migration policy in the context of the employment of foreigners in Poland is described by Solga ${ }^{7}$. The demand-related and structural aspects of the employment of foreigners in Poland

1 Polish Classification of Business Activities.

2 Zuzanna Brudnarska, Małgorzata Grothe, Magdalena Lesińska, Migracje obywateli Ukrainy do Polski w kontekście rozwoju spoteczno-gospodarczego. Stan obecny, polityka transfery pieniężne (Warsaw: Centre of Migration Research, 2012).

3 Jakub Binkowski, "Ukraińcy ratunkiem dla polskiej demografii," in Imigranci wsparciem dla rynku pracy i przedsiębiorstw, ed. Teresa Kupczyk (Wrocław: Wydawnictwo Gazeta Wyborcza, 2017), 7-17.

4 Justyna Szpakowska, Tomasz Buchwald, Robert Romanowski, “Atrakcyjność polskiego rynku pracy dla obywateli Ukrainy: przyczyny, mechanizmy, konsekwencje migracji zarobkowych," Optimum. Studia Ekonomiczne, no. 2 (2016): 163-184.

Michał Lubicz Miszewski, Imigranci z Ukrainy w Polsce. Potrzeby i oczekiwania, reakcje spoteczne, wyzwania dla bezpieczeństwa (Wrocław: Akademia Wojsk Lądowym im. Tadeusza, 2018).

6 Joanna Przemyślańska-Włosek, „Opinia pracowników z Ukrainy na temat pracy w Polsce," in Imigranci wsparciem dla rynku pracy i przedsiębiorstw, ed. Teresa Kupczyk (Wrocław: Wydawnictwo Gazeta Wyborcza, 2017), 7-17.

Brygida Solga, "Polityka migracyjna Polski i jej regionalny wymiar," Studia Ekonomiczne. Zeszyty Naukowe Uniwersytetu Ekonomicznego w Katowicach, no. 290 (2016): 51-60. 
are shown by Piotrowski and Organiściak-Krzykowska ${ }^{8}$. The problems of immigrants on the Polish labour market are outlined in the study by Frelak and Bieniecki ${ }^{9}$. Kałuża-Kopias uses the statistics from the Ministry of Labour and Social Policy to characterise the employment of immigrants in Poland, taking into account their nationalities ${ }^{10}$.

None of the studies available in literature focuses on the employment of Russians in the Polish labour market, and this article aims to fill the gap in the body of research on that subject.

\section{DATA AND METHODS}

In order to investigate the employment of Russians in the Polish labour market, it is necessary to review the provisions of the Polish law which allow employment on the basis of a work permit or without such a permit. The numerical data relating to the employment of foreigners in Poland can be found in the data bases compiled since 2008 by the Ministry of Family, Labour and Social Policy. On the basis of this data, it is possible to determine the number of work permits granted, by PKD section, occupational group and profession, as well as the number of statements by Polish employers wishing to assign work to Russians, by national economy sector.

This study is based on the following research methods: system analysis, comparative methods and quantitative methods, allowing to show the numbers of Russian citizens employed in Poland by PKD section, occupational group and profession.

8 Marek Piotrowski, Anna Organiściak-Krzykowska, "Zatrudnienie cudzoziemców na polskim rynku pracy - aspekty popytowe i strukturalne," Studia Prawno-Ekonomiczne, vol. C (2016): 315-328.

9 Justyna Frelak., Mirosław Bieniecki, "Praktyka funkcjonowania migrantów ekonomicznych w Polsce," in Migranci na polskim rynku pracy. Rzeczywistość, problemy wyzwania, ed. Witold Klaus (Warsaw: Association for Legal Intervention, 2007).

10 Dorota Kałuża-Kopias, "Imigranci na polskim rynku pracy według statystyk MP i PS," Studia Ekonomiczne. Zeszyty Naukowe Uniwersytetu Ekonomicznego w Katowicach, no. 258 (2016): 17-29. 


\section{LEGAL BASES FOR ARRIVALS AND EMPLOYMENT OF RUSSIAN CITIZENS}

Russian nationals may migrate to Poland under international and bilateral agreements concluded between Poland and the Russian Federation. The arrival of Russian nationals seeking refugee status was made possible when Poland signed the Geneva Convention of 28 July 1951, which grants refugees, inter alia, the right to freedom of expression, freedom of movement and choice of residence, the right to take up wage-earning employment and the guarantee of social security ${ }^{11}$. Another form of protection existing in addition to refugee status is subsidiary protection, introduced in Poland in 2008. The Act of 13 June 2003 on granting foreign nationals protection in the territory of the Republic of Poland provides that "Subsidiary protection shall be granted to an alien where their return to the country of origin may expose them to a real risk of serious harm and, because of that risk, they cannot or do not wish to benefit from the protection of the country of origin" 12 . Polish legislation also provides for an alternative form of protection, referred to as tolerated stay, governed by the Act on aliens of 12 December 2013. This type of protection is granted where an alien might be expelled to a country where their life, freedom and personal security would be jeopardised, where they could be subjected to torture, degrading treatment, humiliation, forced to work or deprived of the right to a fair trial, or where their rights relating to family life or their child's rights might be infringed ${ }^{13}$.

The arrival of Russian citizens in Poland to take up employment or education is possible on the basis of bilateral agreements concluded between the two countries. In Article 8 of the Treaty on friendly and good-neighbourly cooperation, Poland and Russia committed themselves to creating favourable conditions for the development of economic activity and the movement of goods, services, labour and capital. Article 13(1) provides

11 Convention Relating to the Status of Refugees, adopted in Geneva on 28 July 1951, Journal of Laws 1991, No. 119, item 515.

12 Act on granting foreign nationals protection in the territory of the Republic of Poland of 13 June 2003, Journal of Laws 2003, No. 128, item 1176.

13 Act on aliens of 12 December 2013, Journal of Laws 2013, item 1650. 
for the development of cooperation in the field of culture, science and education ${ }^{14}$. The agreement on cooperation in the field of science, culture and education stressed that cooperation between universities and research institutions should be based on plans, programs and agreements ${ }^{15}$.

The development of mutual contacts was to be encouraged by the expansion of border crossings ${ }^{16}$. In addition, Poland and Russia signed an agreement on international road transport ${ }^{17}$ and on the travelling conditions of citizens, which agreement stipulates that border crossing between the two states should be based on visas ${ }^{18}$.

Conclusion of the Readmission Agreement between the Russian Federation and the European Community has increased the effectiveness of efforts to combat illegal immigration ${ }^{19}$. Russia's relations with Poland in this area were governed by the implementation protocol between the two states on the implementation of the readmission agreement. It specified the authorities responsible for the implementation of the agreement, the application method, the rules for application processing, the method of escorting of the persons to be readmitted and the coverage of financial costs ${ }^{20}$.

14 Treaty between the Republic of Poland and Russia on friendly and good-neighbourly cooperation signed in Moscow on 22 May 1992, (Journal of Laws 1993, item 291).

15 Agreement between the Government of the Republic of Poland and the Russian Federation on cooperation in the field of science, culture and education signed in Warsaw on 25 August 1993, Journal of Laws 1994, No. 36, item 133.

16 Agreement between the Government of the Republic of Poland and the Government of the Russian Federation on border crossings signed in Moscow on 22 May 1992, Official Gazette of the Republic of Poland (M. P.) of 2003, No 37m, item 528.

17 Agreement between the Government of the Republic of Poland and the Government of the Russian Federation on international road transport, signed in Warsaw on 30 August 1996, Official Gazette of the Republic of Poland (M. P.) of 2005, No. 61, item 806.

18 Agreement between the Government of the Republic of Poland and the Government of the Russian Federation on the travelling conditions of the citizens of the Republic of Poland and the citizens of the Russian Federation of 18 September 2003, Official Gazette of the Republic of Poland (M. P.) of 2003, No. 51, item 800.

19 Readmission Agreement between the Russian Federation and the European Community signed at Sochi on 25 May 2006, OJ L 129/40 of 17.05.2007.

20 Implementation Protocol between the Government of the Republic of Poland and the Government of the Russian Federation on the implementation of the Readmission Agreement between the European Community and the Russian Federation signed in Sochi 
The entry, stay and departure of aliens, as well as their employment are governed by national legislation. The most important statute that enables entry is the Act on aliens, which stipulates that non-EU nationals may cross the EU border if they hold a valid travel document and a visa, the type of which depends on the purpose of entry and stay of the holder ${ }^{21}$.

The 2017 amendment to the Act on aliens introduced a provision stipulating that "A temporary residence and work permits shall also be granted where the purpose of the alien's stay in Poland is to work in an occupation which is desirable for the Polish economy, as defined in the provisions issued pursuant to paragraph 5 , the alien has the vocational qualifications required to engage in that occupation and the cumulative conditions referred to in paragraphs 1, 2, 4 and 5 of paragraph 1 are fulfilled". It is not required to demonstrate that an employer is unable to meet the human resources needs of the local labour market in order for a foreigner to take up an occupation in demand or practise a high-skilled profession. Such foreigners may apply for a permanent residence permit after 4 years of uninterrupted stay in Poland ${ }^{22}$.

Foreign nationals can receive education in Poland by virtue of the provisions of the higher education law ${ }^{23}$. The Russian citizens who took up permanent residence in Poland between 2004 and 2018 included repatriates and Russians who had married a Polish citizen ${ }^{24}$.

The Act on employment promotion and labour market institutions of 20 April 2004 governs the employment of foreign nationals on the basis of a work permit and without such a permit. Foreigners who must apply for permission to work in Poland (Article 88) include those who ${ }^{25}$ :

on 25 May 2006, signed in Moscow on 28 November 2012, Official Gazette of the Republic of Poland (M. P.) of 2015, item 525.

21 Act on aliens of 12 December 2013, Journal of Laws 2013, item 1650.

22 Act amending the Act on aliens and certain other acts of 24 November 2017, Journal of Laws 2018, item 107.

23 Act of 12 September 1990 on higher education, Journal of Laws 1990 No 37, item 385 .

24 Demographic Yearbook 2004-2018 (Warszawa: Wydawnictwo GUS, 2005-2019).

25 Notice of the Marshal of the Sejm of the Republic of Poland on the announcement of the consolidated Act on employment promotion and labour market institutions of 07 June 2018, Journal of Laws 2018, item 1265. 
1. perform work in the territory of Poland on the basis of an employment contract with an entity whose head office, branch or establishment is based in Poland;

2. hold a position in the Management Board of a legal person entered in the register of entrepreneurs and stay in Poland for a period exceeding 6 months over a period of 12 consecutive months;

3. work for a foreign employer and are posted to its Polish branch or establishment for a period of more than 30 days within a calendar year;

4. work for a foreign employer without a branch or establishment in Poland for the purpose of an export service;

5. work for a foreign employer in Poland for a period exceeding 30 days within 6 consecutive months for a purpose other than those indicated in the preceding paragraphs.

The types of permits issued are identified in Article 88 of the Act on employment promotion and labour market institutions of 2004 and the regulation of the Minister of Labour and Social Policy of 07 December 2017 on the issue of work permits ${ }^{26}$ :

- Type A permit may be issued to an alien who performs work in the territory of Poland on the basis of an employment contract with an employer whose registered office, place of residence, branch, establishment or other form of activity is situated in the territory of Poland;

- Type B permit may be issued to a foreigner holding a position in the Management Board of a legal person entered in the register of entrepreneurs or a capital company in the process of formation, if they stay in the territory of Poland for a period exceeding six months within a consecutive 12 months;

- Type C permits is issued to a foreign national who performs work for a foreign employer and is posted to the territory of Poland for a period exceeding 30 days in a calendar year, to a branch or estab-

26 Regulation of the Minister of Family, Labour and Social Policy on the issue of aliens' work permits and the entry of a declaration on the assignment of work to an alien in the register of statements of 07 December 2017, Journal of Laws 2017, item 2345. 
lishment of a foreign entity or an affiliated entity within the meaning of the Act of 26 July 1991 on income tax on natural persons;

- Type D can be received by an alien working for a foreign employer without a branch or establishment in Poland, for the purpose of an export service;

- Type E permit is issued to foreign nationals who works for a foreign employer and is posted to the territory of Poland for a period exceeding 3 months within a period of consecutive 6 months for a purpose other than those indicated in items 2 to 4 .

Immigrants whose stay in Poland is considered undesirable ${ }^{27}$ cannot expect to be employed in the territory of Poland.

The requirement of obtaining a work permit does not apply (Article 87) to foreigners who:

1) hold a permit for temporary residence in Poland under: Article 144 - for the purposes of studying in bachelor's, master's or doctoral courses; Article 151 - a temporary residence permit for the purposes of scientific research; Article 151b(1) - a long-term researcher's mobility permit; Article 158(2)(1) or (2) meeting the conditions for granting a temporary residence permit for a member of the family of a Polish citizen (being in a marriage recognized by the Polish law with a Polish national or being a minor child of a Polish national); Article 161 - meeting the conditions for granting a temporary residence permit to a member of the family of an alien for the purpose of family reunification; Article 176(2) - meeting the conditions for granting a temporary residence permit to victims of human trafficking; Article 186(1)(3), (4) or (7) of the Aliens Act of 12 December 2013 - meeting the conditions for a mandatory temporary residence permit based on other circumstances (persons holding a long-term EU residence permit granted by another Member State if: (a) they intend to work or conduct economic activity in Poland; (b) they intend to undertake or continue their studies or vocational training; (c) the alien: demonstrates that there are other circumstances justifying their residence in Poland; is a member of the family of an alien with whom they have been residing in the territory of another Member State is accompanied by or wishes to

27 Act on the effects of the assignment of work to aliens unlawfully staying in the territory of the Republic of Poland of 15 June 2012, Journal of Laws 2012, No. 769. 
join them; immediately prior to the application for residence permit, was resident in Poland on the basis of a temporary residence permit for the purpose of carrying out scientific research which they either completed and are seeking work in Poland or planning to undertake economic activity, and when a national visa was granted to a foreign national visa for the purpose of carrying out scientific research or development work;

(2) are married to a Polish national or a foreign national referred to items 1 to 6 of paragraph 1 (refugee, recipient of subsidiary protection, permanent residence permit, long-term resident of the European Union, humanitarian residence, tolerated stay, recipient of temporary protection) or hold a permit for temporary residence in Poland granted in connection with their marriage;

(3) are a descendant (aged 21 years or dependant) referred to in Article $2(1)(8)(B)$ of a Polish national or a foreign national referred to in points 1-2 and paragraph 1(1-6) (refugee, recipient of subsidiary protection, permanent residence permit, long-term resident of the European Union, humanitarian residence, tolerated stay, recipient of temporary protection) and hold a permit for a temporary stay in Poland;

(4) hold a permit for temporary residence in Poland granted pursuant to Article 159(1) - meeting the conditions for a mandatory temporary residence permit for the purpose of family reunification, or Article 161b(1) on account of the long-term stay of a member of the family of a researcher, where the purpose of their stay in the territory of Poland is to stay with the researcher in accordance with the Act of 12 December 2013 on aliens;

(5) are staying in Poland on the basis of Article 108(1)(2) (confirmation of an application for temporary residence) or of Article 206(1)(2) (confirmation of an application for permanent residence) of the Act of 12 December 2013 on aliens, or on the basis of a stamp affixed to the travel document, which confirms the application for a long-term resident's EU residence permit when an alien has been exempted from the obligation to hold a work permit prior to the application;

6) hold a valid Pole's Card (Karta Polaka);

7) are entitled to reside and work in the territory of an EU Member State, the European Economic Area or of the Swiss Confederation, employed by an employer established in the territory of that State and temporarily posted by that employer to provide services in Poland; 
8) are allowed to work without a work permit under international agreements $^{28}$.

The detailed rules for foreign nationals performing work without a work permit are laid down in the Regulation of the Ministry of Labour and Social Policy of 21 April 2015. The persons who can work on this basis include: 1/ instructors, advisers, supervisors working in EU support programmes; 2/ language teachers undertaking employment in kindergartens, schools, institutions, centres, teacher training establishments, colleges or OHP voluntary labour corps; $3 /$ members of the armed forces or civilian staff working in international military structures on the basis of agreements concluded by Poland; 4/ permanent foreign correspondents who hold media accreditation; $5 /$ persons performing artistic services - up to 30 days a year; $6 /$ persons giving occasional lectures - up to 30 days a year; $7 /$ athletes taking part in sporting events - up to 30 days a year; 8/ other persons working in connection with international sports events; $9 /$ clergy and members of religious orders - in connection with their functions in churches and religious organisations; 10/ undergraduate, postgraduate and doctoral students; $11 /$ students in vocational training and student organisations leaders; 12/ students working in public employment services and their foreign partners; 13/ students and pupils from European Union countries, the European Economic Area or the Swiss Confederation who perform work within the framework of vocational practices as provided for by the study regulations or the curriculum; 14/ participants in cultural or educational exchange programmes, humanitarian or development aid programmes, or student holiday employment programmes organised by the Minister for Labour; 15/ graduates of Polish upper secondary schools, universities or full-time doctoral studies at Polish universities, Polish Academy of Science institutes or other research institutions; 16/ persons who conduct research as academic workers; $17 /$ persons posted by a foreign employer to Poland for a period not exceeding 3 months in a calendar year for the purpose of: a/ carrying out assembly, maintenance, repair of equipment, machinery or other equipment manufactured by the foreign employer; $b /$ collection of ordered machinery or equipment manufactured by

28 Act on employment promotion and labour market institutions of 20 April 2004, Journal of Laws 2018, item 1265. 
a Polish entrepreneur, c) training of employees of the Polish employer who is the recipient of the equipment, constructions or machinery; d) looking after exhibition stands of the foreign employer ${ }^{29}$.

\section{THE NATURE OF THE RESIDENCE OF RUSSIAN CITIZENS IN POLAND AND EMPLOYMENT OPPORTUNITIES}

Between 2004 and 2018, Russian citizens arrived in Poland to settle there permanently or for a limited period. The third group consisted of Russian citizens seeking international protection. Details of the time and nature of the Russians' arrivals in Poland are given in Table 1.

29 Regulation of the Minister of Labour and Social Policy on cases in which the assignment of work to an alien in the territory of the Republic of Poland is permitted without the need for a work permit of 21 April 2015, Journal of Laws 2015, item 588. 


\begin{tabular}{|c|c|c|c|c|c|c|c|c|c|c|c|c|c|c|c|}
\hline 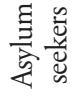 & 0 & 0 & 0 & 0 & 0 & 0 & 0 & 0 & 0 & 0 & 0 & - & 0 & 0 & 0 \\
\hline 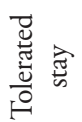 & $\stackrel{\infty}{n}$ & 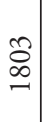 & $\frac{n}{\tilde{\sigma}}$ & 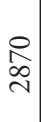 & $\begin{array}{l}\stackrel{\circ}{\perp} \\
\stackrel{+}{+}\end{array}$ & $\widetilde{6}$ & $\stackrel{0}{\Xi}$ & $\stackrel{ }{\beth}$ & $\underset{丶}{\stackrel{\sim}{\sim}}$ & s & ชิ & $\overrightarrow{0}$ & $\underset{7}{F}$ & $\stackrel{\infty}{\sim}$ & $I$ \\
\hline
\end{tabular}

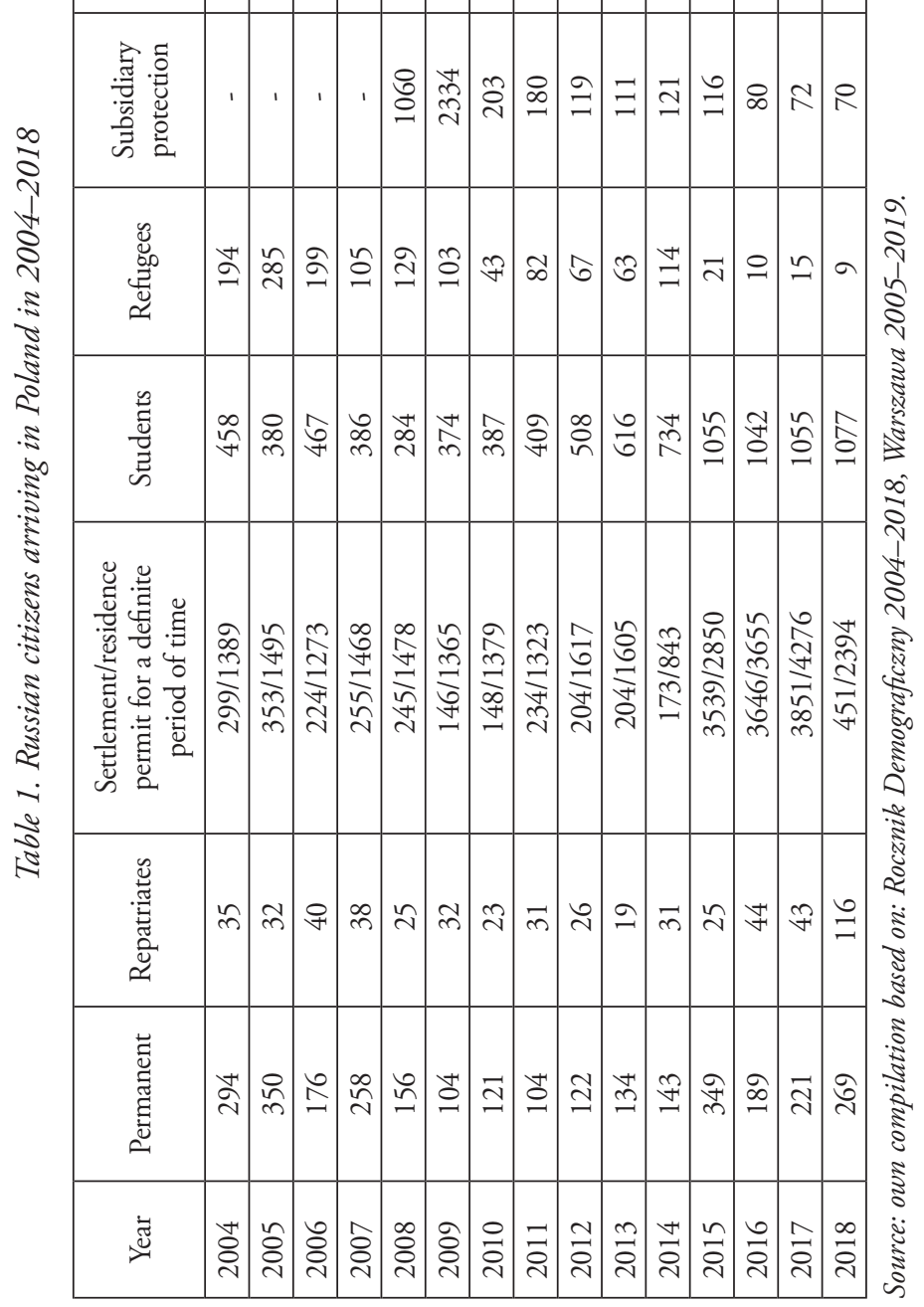


The data in Table 1 shows that the number of Russians arriving in Poland increased between 2004 and 2018. Every year, several hundred people arrived in Poland to settle there permanently. A majority of those were Russian citizens who made that decision having married a Polish citizen. The repatriates represented a less numerous group, although their number increased steadily in the period investigated. The largest group comprised citizens of the Russian Federation who came to Poland for a limited period. A substantial proportion of those were students doing undergraduate and postgraduate studies at Polish universities, of all types. The largest groups of students studied at major Polish universities: University of Warsaw, Jagiellonian University, Nicolaus Copernicus University in Toruń, and the University of Wrocław ${ }^{30}$.

After Poland's accession to the European Union, a large number of Russian Federation citizens came to Poland, mainly Chechens seeking refugee status. Only a few of them fulfilled the requirements of the Geneva Convention $^{31}$ and acquired such status. Many more Russians were granted tolerated stay and subsidiary protection status. Between 2004 and 2018 only one Russian citizen received asylum in Poland. According to the findings of Polish researchers, few Chechens were interested in staying in Poland or taking up any work. More than $90 \%$ of the arrivals in Poland left Poland within two years to move to Western European countries ${ }^{32}$.

Citizens of the Russian Federation residing in Poland legally were allowed to undertake employment. The number of Russians granted work permits as compared to the overall number of foreigners is shown in Table 2.

30 Krystyna Gomółka, Polityka Polski wobec studentów, doktorantów i stażystów z państw poradzieckich (Toruń: Wydawnictwo Adam Marszałek, 2016), 114.

31 Convention Relating to the Status of Refugees, adopted in Geneva on 28 July 1951, Journal of Laws 1991, No. 119, item 515.

32 Adam Białous, "Kim są Czeczeńcy żyjący w naszym kraju. Najliczniejsi „uchodźcy” wybudzają różne opinie,” January 1, 2020, https://www.pch24.pl/kim-sa-czeczeni-zyjacy-w-naszym-kraju--najliczniejsi-uchodzcy-wzbudzaja-rozne-opinie-,49119,i.html. 
Table 2. Citizens of the Russian Federation granted work permits in 2004-2018

\begin{tabular}{|c|c|c|}
\hline Year & Total number of permits issued to aliens & $\begin{array}{c}\text { Number of permits for Russian } \\
\text { citizens }\end{array}$ \\
\hline 2004 & 13,179 & 584 \\
\hline 2005 & 11,151 & 594 \\
\hline 2006 & 12,063 & 543 \\
\hline 2007 & 14,798 & 547 \\
\hline 2008 & 18,022 & 420 \\
\hline 2009 & 29,340 & 540 \\
\hline 2010 & 36,622 & 491 \\
\hline 2011 & 40,808 & 549 \\
\hline 2012 & 39,144 & 719 \\
\hline 2013 & 39,078 & 822 \\
\hline 2014 & 43,663 & 654 \\
\hline 2015 & 65,786 & 579 \\
\hline 2016 & 127,394 & 1008 \\
\hline 2017 & 235,628 & 1433 \\
\hline 2018 & 328,768 & 2190 \\
\hline
\end{tabular}

Source: own compilation based on: Demographic Yearbook 2004-2018, Warsaw 2005-2019. 
In 2004, Russians accounted for $4.4 \%$ of foreigners and in 2018 for $0.66 \%$ of all foreigners who were permitted to work in Poland. The number of Russians employed increased since 2004, as did the overall number of foreigners entering employment in Poland. Table 3 shows the types of work permits issued in the period 2010-2018.

Table 3. Number of Russian nationals who have entered employment in 2010-2018, by type of permit

\begin{tabular}{|l|c|c|c|c|c|c|c|c|c|}
\hline $\begin{array}{l}\text { Type of } \\
\text { permit }\end{array}$ & 2010 & 2011 & 2012 & 2013 & 2014 & 2015 & 2016 & 2017 & 2018 \\
\hline A & 392 & 471 & 622 & 698 & 576 & 504 & 946 & 1362 & 1913 \\
\hline B & 60 & 56 & 65 & 71 & 41 & 23 & 18 & 35 & 33 \\
\hline C & 32 & 18 & 25 & 42 & 27 & 36 & 34 & 56 & 87 \\
\hline D & 7 & 1 & 5 & 1 & 0 & 4 & 8 & 13 & 144 \\
\hline E & 0 & 0 & 2 & 10 & 10 & 12 & 2 & 8 & 13 \\
\hline
\end{tabular}

Source: own compilation based on: Cudzoziemcy pracujacy w Polsce. Statystyki, https://archiwum.mpips.gov.pllanalizy-i-raporty/cudzoziemcy-pracujacy-w-polsce-statystykil (access date: 19.12.2019).

The largest number of Russians were granted type A permits, i.e. permits to perform work under an employment contract with an employer whose registered office is in Poland. The fewest Russians received type E permits, i.e. for employees posted to Poland to perform a specific task. Table 4 shows a breakdown of statistics relating to Russian employees in Poland by selected occupational groups and professions. 


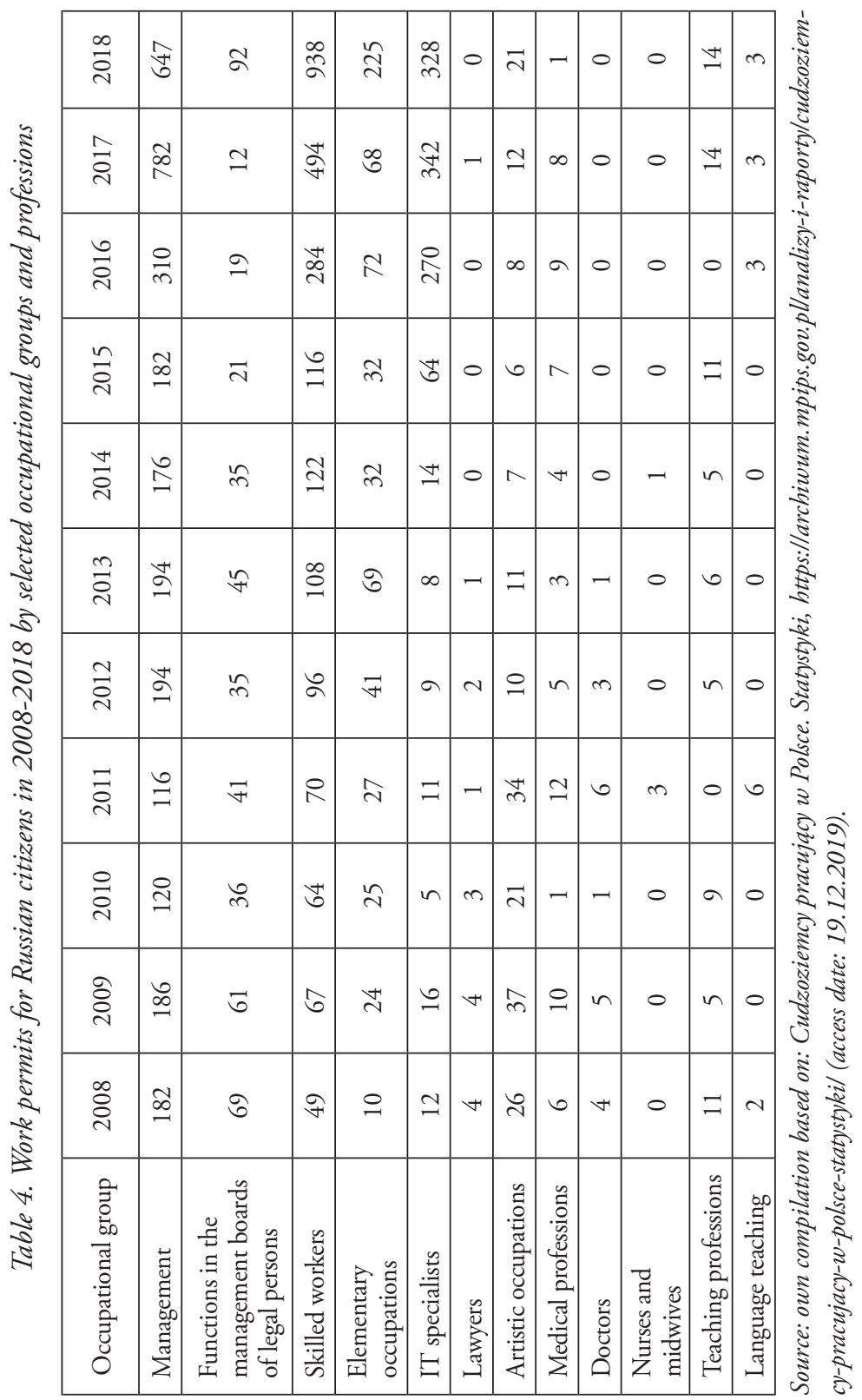


The data shown in Table 4 suggest that the Russian citizens who took up employment in Poland between 2004 and 2015 were mainly managers, often of their own companies ${ }^{33}$. Since 2015 , there has been a steady increase in the number of skilled workers and workers in elementary occupations who entered employment in Poland. The number of Russian IT specialists also grew since 2015. Other occupational groups and professions did not attract many Russians entering Poland. The number of work permits by PKD (Polish classification of business activities) section is shown in Table 5.

33 Tomasz Dziewulski, "Co jest rosyjskie w Polsce?," December 10, 2019, https:// wspieramrozwoj.pl/artykul/66/rosyjskie-produkty-i-firmy-w-polsce . 


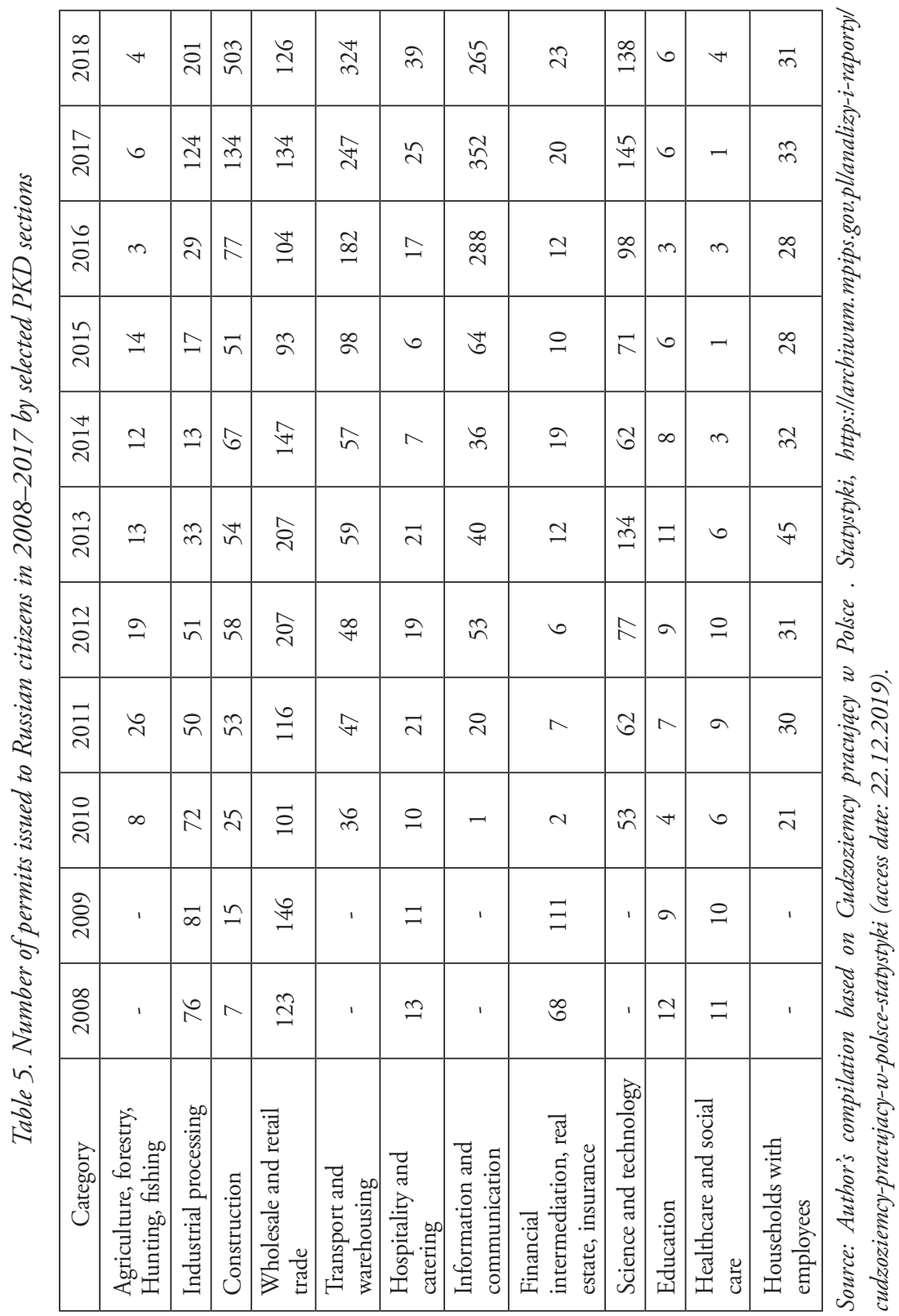


The data presented in Table 5 indicate that in 2008-2018 the largest number of Russians were permitted to work in the wholesale and retail trade sector, information and communication, construction, transport and warehousing, whereas the fewest work permits were issued to Russians seeking employment in the education, healthcare and social welfare sector.

Since 2008, Polish employers have been able to submit statements on the assignment of work to an alien. Table 6 shows the number of employers' statements on the assignment of work to Russians by PKD section in 2008-2018.

Table 6. Employers' statements on the assignment of work to Russians by national economy sector in 2008-2018

\begin{tabular}{|l|l|l|l|l|l|l|l|l|l|l|l|}
\hline \multicolumn{1}{|c|}{ Category } & 2008 & 2009 & 2010 & 2011 & 2012 & 2013 & 2014 & 2015 & 2016 & 2017 & 2018 \\
\hline $\begin{array}{l}\text { Agriculture, } \\
\text { forestry, } \\
\text { hunting, fishing }\end{array}$ & 91 & 131 & 188 & 123 & 184 & 134 & 152 & 331 & 449 & 363 & 17 \\
\hline $\begin{array}{l}\text { Mining and } \\
\text { quarrying }\end{array}$ & - & - & - & - & - & - & 2 & 1 & 1 & 14 & 7 \\
\hline $\begin{array}{l}\text { Industrial } \\
\text { processing }\end{array}$ & - & - & - & 54 & 109 & 116 & 114 & 176 & 411 & 660 & 724 \\
\hline $\begin{array}{l}\text { Electrical energy } \\
\text { production, } \\
\text { water and gas } \\
\text { supply }\end{array}$ & - & - & - & - & - & - & 5 & 2 & 0 & 0 & 0 \\
\hline $\begin{array}{l}\text { Water supply, } \\
\text { wastewater } \\
\text { and waste } \\
\text { management }\end{array}$ & - & - & - & - & - & - & 10 & 4 & 32 & 65 & 10 \\
\hline $\begin{array}{l}\text { Construction } \\
\text { and related }\end{array}$ & 182 & 55 & 74 & 182 & 412 & 159 & 140 & 222 & 495 & 910 & 514 \\
\hline $\begin{array}{l}\text { Wholesale and } \\
\text { retail trade }\end{array}$ & 233 & 149 & 62 & 90 & 170 & 183 & 168 & 167 & 253 & 429 & 145 \\
\hline
\end{tabular}




\begin{tabular}{|c|c|c|c|c|c|c|c|c|c|c|c|}
\hline Category & 2008 & 2009 & 2010 & 2011 & 2012 & 2013 & 2014 & 2015 & 2016 & 2017 & 2018 \\
\hline Industry & 223 & 178 & 60 & 0 & 0 & 0 & 0 & 0 & 0 & 0 & 0 \\
\hline $\begin{array}{l}\text { Transport } \\
\text { Warehousing }\end{array}$ & 72 & 31 & 40 & 77 & 80 & 98 & 74 & 155 & 403 & 509 & 394 \\
\hline $\begin{array}{l}\text { Catering, } \\
\text { hospitality, } \\
\text { storage }\end{array}$ & 31 & 32 & 25 & 33 & 40 & 40 & 20 & 55 & 114 & 212 & 81 \\
\hline $\begin{array}{l}\text { Information and } \\
\text { communication }\end{array}$ & - & - & - & 21 & 17 & 39 & 137 & 261 & 411 & 263 & 158 \\
\hline $\begin{array}{l}\text { Financial and } \\
\text { insurance } \\
\text { activities }\end{array}$ & - & - & - & 9 & 10 & 16 & 17 & 22 & 22 & 31 & 15 \\
\hline $\begin{array}{l}\text { Real estate } \\
\text { activities }\end{array}$ & 0 & 0 & 0 & 0 & 0 & 0 & 2 & 12 & 9 & 21 & 19 \\
\hline $\begin{array}{l}\text { Professional } \\
\text { activities, science } \\
\text { and technology }\end{array}$ & - & - & - & 27 & 62 & 39 & 48 & 80 & 104 & 186 & 55 \\
\hline $\begin{array}{l}\text { Administrative } \\
\text { services }\end{array}$ & - & - & - & - & - & - & 93 & 227 & 925 & 2172 & 372 \\
\hline $\begin{array}{l}\text { Public } \\
\text { administration, } \\
\text { national defence, } \\
\text { compulsory } \\
\text { social security }\end{array}$ & - & - & - & - & - & - & 13 & 1 & 1 & 2 & 0 \\
\hline Education & - & - & - & 6 & 9 & 6 & 9 & 28 & 18 & 13 & 10 \\
\hline $\begin{array}{l}\text { Health care and } \\
\text { social welfare }\end{array}$ & - & - & - & 21 & 14 & 3 & 4 & 13 & 30 & 28 & 14 \\
\hline $\begin{array}{l}\text { Culture and } \\
\text { entertainment }\end{array}$ & - & - & - & - & - & - & 58 & 23 & 37 & 45 & 23 \\
\hline Other services & - & - & - & - & - & - & 131 & 109 & 102 & 179 & 79 \\
\hline $\begin{array}{l}\text { Households with } \\
\text { employees }\end{array}$ & 21 & 21 & 22 & 32 & 52 & 53 & 32 & 50 & 51 & 38 & 9 \\
\hline
\end{tabular}




\begin{tabular}{|l|l|l|l|l|l|l|l|l|l|l|l|}
\hline \multicolumn{1}{|c|}{ Category } & 2008 & 2009 & 2010 & 2011 & 2012 & 2013 & 2014 & 2015 & 2016 & 2017 & 2018 \\
\hline $\begin{array}{l}\text { Temporary work } \\
\text { agencies }\end{array}$ & 28 & 32 & 27 & 0 & 0 & 0 & 0 & 0 & 0 & 0 & 0 \\
\hline Other & 259 & 127 & 200 & 288 & 465 & 371 & - & - & - & - & - \\
\hline
\end{tabular}

Source: Author's compilation based on: Cudzoziemcy pracujacy w Polsce. Statystyki, https://archiwum.mpips.gov.pllanalizy-i-raporty/cudzoziemcy-pracujacy-w-polsce-statystykil (access date: 29.12.2019).

According to employers, Russian workers were in highest demand in wholesale and retail, construction, transport, as well as information and communication sectors, and since 2014 also in administration services. The fewest statements concerning Russian employees were submitted in the sectors of electrical energy production, water and gas supply, mining and quarrying, public administration, national defence and social security.

\section{CONCLUSIONS}

Russians may enter Poland legally on the basis of international and bilateral agreements signed by Poland and Russia. They may receive refugee status under the Geneva Convention, subsidiary protection on the basis of the Polish Act on granting protection to aliens, or be granted tolerated stay on the basis of the Law on aliens. The conditions for undertaking university studies are laid down by the Polish Higher Education Act, whereas the Act on employment promotion and labour market institutions governs the rules of entering employment. Between 2004 and 2018, relatively few Russians, including repatriates, arrived to settle in Poland permanently. A majority of Russians came to Poland for a limited period of time. That group included students and people who intended to seek employment in Poland. The Russian Federation citizens having refugee status were not interested in finding jobs in Poland; most of them were Chechens, who left Poland within two years of arrival to move to Western European countries.

In 2004, Russian nationals represented $4.4 \%$ and in $2018-0,66 \%$ of all foreigners who received work permits in Poland. A majority were granted A type permits, and the fewest acquired type E permits. Between 2004 
and 2015, Russians often took up work in Poland as managers, often of their own companies. Since 2015, there has been an increase in the numbers of workers from Russia in three occupational groups: IT specialists, skilled workers and workers in elementary occupations. In 2004-2018, the largest numbers of Russian workers were employed in the wholesale, retail, information and communication, construction, transport and warehousing sectors. These were the industries where Polish employers wished to hire them, as evidenced by the submitted statements on the assignment of work to Russian nationals. The demand for Russian workers exceeded the number of employees, so the Polish labour market offered employment opportunities for a more numerous group of Russians.

\section{REFERENCES}

Białous, Adam. "Kim są Czeczeńcy żyjący w naszym kraju. Najliczniejsi „uchodźcy" wybudzają różne opinie." PCh24.pl Polonia Christiana 2017, https:// www.pch24.pl/kim-sa-czeczeni-zyjacy-w-naszym-kraju--najliczniejsi-uchodzcy-wzbudzaja-rozne-opinie-49119,i.html.

Binkowski, Jakub. "Ukraińcy ratunkiem dla polskiej demografii." In Imigranci wsparciem dla rynku pracy i rozwoju przedsiębiorstw, edited by Teresa Kupczyk, 7-17. Wrocław: Wydawnictwo Gazeta Wyborcza, 2017.

Brudnarska, Zuzanna, Małgorzata Grothe, and Magdalena Lesińska. Migracje obywateli Ukrainy do Polski w kontekście rozwoju spoteczno-gospodarczego. Stan obecny, polityka transfery pieniężne. Warszawa: Ośrodek Badań nad Migracjami, 2012.

"Cudzoziemcy pracujący w Polsce. Statystyki." Ministerstwo Rodziny, Pracy i Polityki Społecznej, December 19-29, 2019, https://archiwum.mpips.gov.pl/ analizy-i-raporty/cudzoziemcy-pracujacy-w-polsce-statystyki/.

Dziewulski, Tomasz."Co jest rosyjskiew Polsce?." WspieramRozwoj.PL, April 10, 2014 , https://wspieramrozwoj.pl/artykul/66/rosyjskie-produkty-i-firmy-w-polsce.

Frelak, Justyna, and Mirosław Bieniecki. „Praktyka funkcjonowania migrantów ekonomicznych w Polsce." In Migranci na polskim rynku pracy. Rzeczywistośc, problemy wyzwania, edited by Witold Klaus, 45-60. Warszawa: Stowarzyszenie Interwencji Prawnej, 2007.

Gomółka, Krystyna. Polityka Polski wobec studentów, doktorantów i stażystów z państw poradzieckich. Toruń: Wydawnictwo Adam Marszałek, 2016. 
Kałuża-Kopias, Dorota. "Imigranci na polskim rynku pracy według statystyk MP i PS." Studia Ekonomiczne. Zeszyty Naukowe Uniwersytetu Ekonomicznego w Katowicach, no. 258 (2016): 17-28.

Matkowska, Marzena. "Migranci na polskim rynku pracy." Studia i Prace Wydziatu Nauk Ekonomicznych i Zarzadzania Uniwersytetu Szczecińskiego, no. 25 (2012): 77-90.

Miszewski Lubicz, Michał. Imigranci z Ukrainy w Polsce. Potrzeby $i$ oczekiwania, reakcje spoteczne, wyzwania dla bezpieczeństwa. Wrocław: Akademia Wojsk Lądowych im. Tadeusza Kościuszki, 2018.

Piotrowski, Marek, and Anna Organiściak-Krzykowska. "Zatrudnienie cudzoziemców na polskim rynku pracy - aspekty popytowe i strukturalne.” Studia Prawno-Ekonomiczne, vol. C (2016): 315-328.

Przemyślańska-Włosek, Joanna. "Opinia pracowników z Ukrainy na temat pracy w Polsce." In Imigranci wsparciem dla rynku pracy i przedsiębiorstw, edited by Teresa Kupczyk, 87-106. Wrocław: Wydawnictwo Gazeta Wyborcza, 2017.

Rocznik Demograficzny 2004-2018. Warszawa: Wydawnictwo GUS, 2005-2019. Solga, Brygida. "Polityka migracyjna Polski i jej regionalny wymiar." Studia Ekonomiczne. Zeszyty Naukowe Uniwersytetu Ekonomicznego w Katowicach, no. 290 (2016): 51-60.

Szpakowska, Justyna, Tomasz Buchwald, and Robert Romanowski. "Atrakcyjność polskiego rynku pracy dla obywateli Ukrainy: przyczyny, mechanizmy, konsekwencje migracji zarobkowych." Optimum. Studia Ekonomiczne, no. 2 (2016): 163-184. 